\title{
Packing Committees in the US House: Strategic Use of the Territorial Delegates After 1970
}

\author{
Cameron DeHart*
}

September 30, 2019

\begin{abstract}
Non-voting delegates have represented territories in Congress since 1797, but have only been able to vote in committees in the last half century. The institutional changes that expanded delegates' rights coincided with rising polarization and partisanship in Congress, but we know little about the relationship between these reforms and these trends. I argue that these changes can be best understood through the lens of partisan conflict. The paper's main finding is that the addition of delegates to standing committees in the 1970s, as well as the Committee of the Whole in the 1990s, increased Democrats' seat share relative to the margin on the floor. This paper places delegates' rights into the context of increasing polarization and partisanship, and explains why conflict over these marginal legislators has become a regular feature of American politics over the last half century.
\end{abstract}

Keywords: Congress, House of Representatives, Party cartel theory, Deck Stacking, Committee packing, Committee of the Whole, Nonvoting delegates, Territorial delegates

*Stanford University, Department of Political Science 
“[House Democrats] are again using the Constitution as a political Handiwipe and extending full voting rights to favored rotten boroughs...Democrats once stood for one man, one vote. Today on the floor of the House, they stand for one Samoan, 10 votes. Vote this down."

Rep. Phil English (R-PA) in 2007 debate over delegate voting in Committee of the Whole

When the new Democratic majority took control of the House in early 2019, the first rules changes they made extended privileges to the nonvoting delegates that represent D.C., Puerto Rico, and the U.S. territories. House Democrats were restoring partial voting rights that had been rescinded by the GOP in 2011, echoing their rule change in 2007 to reinstate delegate voting after 12 years of Republican control. The rule in question, allowing delegates to vote on amendments in Committee of the Whole, had only been around since 1993, but as the quote from Representative English reveals, conflict over delegate voting is fierce and divided along party lines.

Partisan theories of Congress suggest that the majority party tries to design institutions in order to improve its control over legislative outcomes, chiefly through the House rules and the committee system (Cox and McCubbins 1993, 2005). Several scholars have investigated the extent to which the majority party in Congress "packs" committees - giving its members more seats than the party's share of seats in the chamber would warrant. One strand of literature examines the over-representation of the majority party on standing committees (e.g. Rohde 1991, Aldrich and Rohde 2000, Aldrich and Rohde 2001, Sinclair 2006, Jenkins and Monroe 2014), and another investigates packing in conference committees (e.g. Lazarus and Monroe 2007, Vander Wielen and Smith 2011).

In this paper, I argue that the majority party has historically used the territorial delegates to pack House committees in at least two previously unknown ways. I present new evidence that the majority party has used the delegates to pack both standing committees and Committee of the Whole (hereafter referred to as "CotW") to improve their influence over policy-making. The addition of delegates to committees results in greater representation for the majority party, which has the potential to shift the committee median closer to the majority party median. These findings demonstrate that the majority party deploys committee packing more extensively than previously 
recognized.

Delegate seats have existed in the House since the 18th century, but the modern version of the office has gained new prominence in an era of increased polarization and partisanship. ${ }^{1}$ Although this article focuses on the majority party's ability to pack committees, it also contributes to our understanding of the territorial delegates and their place in the American political system. Among other things, the delegates provide an opportunity to evaluate partisan theories of organization in a different context (Lewallen 2017). ${ }^{2}$

In this paper I argue that in an era of extreme partisanship, there is no limit to the majority party's willingness, and increasing reliance, on "small gun" strategies that impart an advantage on the margins of the legislative process. By exploring how Democrats in the House majority deployed delegates on the margins we learn that no tactic is beyond the majority's consideration, no matter how obscure. Third, this research has implications for other legislatures that deal with peripheral members, including Maine (non-voting members) and parliaments, which sometimes incorporate colonial possessions and designated seats for ethnic groups (e.g. New Zealand, Romania).

The paper proceeds as follows. First, I present background on the office of nonvoting delegate and theories of committee packing, followed by a framework for thinking about how delegates can be added to committees strategically. To test my theory, I first present evidence that the addition of territorial delegates to standing committees resulted in an increase in the extent to which Democrats were over-represented in those committees. The addition of delegates was also associated with increasing committee sizes, suggesting that the majority party used expansion rather than replacement to pack standing committees with delegates. Next, I explore the majority's decision to give delegates the right to vote in CotW. Drawing on newly-collected CotW votes, I estimate the

\footnotetext{
${ }^{1}$ The six current delegates represent D.C. and the U.S. territories: Puerto Rico, Guam, U.S. Virgin Islands, American Samoa, and the Northern Mariana Islands.

${ }^{2}$ A recent issue of PS: Political Science \& Politics featured a Symposium on teaching the U.S. territories (Vol.50, Issue 2-April 2017). The Symposium joins just four other articles that address non-voting delegates in American politics: Lewallen \& Sparrow (2018), Holtzman (1987), Stewart $\&$ Weingast (1992), and McCarty, Poole, and Rosenthal (2000).
} 
delegates' ideal points and show that their addition moved the CotW median closer to the majority party median. The paper concludes with evidence that the minority party opposed these strategies each time they were deployed, and that conservatives tried to create loyal delegate seats of their own.

\section{Background}

\section{Territorial Delegates in the House Rules}

The U.S. Constitution gives Congress the authority to "dispose of and make all needful rules and regulations respecting the territory or other property belonging to the United States" (Article IV, Section 3). To that end, the House of Representatives permits residents living in the territories to elect a delegate to serve on their behalf and advise members on relevant policy areas. Non-voting delegates have served in every Congress since 1793, with the exception of the 5th Congress, but the non-voting delegates represented territories that were destined for statehood until the 20th century. ${ }^{3}$ The acquisition of Puerto Rico and the Philippines in the late 19th century marked a departure from that tradition - in the nation's history, 27 territories sent delegates to the House before reaching statehood, and 7 territories elected delegates without a path to statehood.

The function of the territorial delegates prior to the 20th century was to advise Congress on local affairs and relevant legislation, and to help build legislative and political talent within the territory before statehood (Holtzman 1986). Historical delegates were active participants in standing, special, and conference committees in various periods before the $1970 \mathrm{~s},{ }^{4}$ and several delegates went on to represent their states in Congress, as governor, and, once, as President of the United

\footnotetext{
${ }^{3}$ The exception is D.C., which had a delegate from 1871 to 1874 .

${ }^{4}$ Delegates could serve on, but not vote in, standing committees from 1871 to 1970 . Rules changes in the 1870s-80s designated the territorial delegates as additional members on the Committee on the Territories, the Committee for the District of Columbia, and others, but they were denied seniority rights (Palmer 2006). The Legislative Reorganization Act of 1946 once again restricted the delegates' rights in committees. Delegates were limited to serving as non-voting additional members on just three committees: Agriculture, Armed Services, and Public Lands (later called Interior and Insular Affairs).
} 
States. $^{5}$

Today, the territorial delegates approximate the House members in terms of the privileges, rights, and powers they can exercise in office. ${ }^{6}$ Since the delegates are not constitutional members of Congress, they can neither cast votes on the floor nor file discharge petitions. Delegates also may not preside over the floor, vote for the House speaker, or sign another member's discharge petition. By virtue of not having the right to vote on the floor, the delegates and their constituents are shut out from important legislative action such as filing motions to reconsider, voting on Constitutional amendments, declaring war, breaking ties in the Electoral College, and resolving disputes over the president's fitness to govern under the 25th amendment. Delegates today also serve as the sole federal representatives of their territory, and lack "ready-made allies" from the same constituency with whom they can share labor and advance legislation (Holtzman 1986).

In this context of increasing partisanship in the House, the non-voting delegates took on new legislative importance: the majority party was able to use the non-voting delegates to increase their procedural control over the House. Previous studies have not considered the creation and empowerment of territorial delegates as a form of committee packing, and given that only five new delegates have been created since 1970, the strategy is clearly not used with much frequency. Still, the strategic addition of new delegates to the committee system represented a significant change in how the parties exert control over procedure when they cannot otherwise control policy. Despite the obscurity of the institution itself, the majority party thought the marginal effect of adding territorial delegates to committees was worthwhile to pursue time and time again. On the other hand, the minority party thought the addition of delegates posed a sufficient threat not only to oppose it on the floor and in federal court, but also to attempt to create delegate seats on their side of the aisle.

Partisan theories of Congress suggest that the majority party tries to design institutions in order to improve its control over legislative outcomes, chiefly through the House rules and the commit-

\footnotetext{
${ }^{5}$ William Henry Harrison, ninth President of the United States, served as the Northwest Territory delegate (1799-1800).

${ }^{6}$ Rule III, Clause 3 of the House Rules stipulates the delegates' powers.
} 
tee system (Cox and McCubbins 1993, 2005). Several scholars have investigated the extent to which the majority party in Congress "packs" committees - giving its members more seats than the party's share of seats in the chamber would warrant. One strand of literature examines the over-representation of the majority party on standing committees (e.g. Rohde 1991, Aldrich and Rohde 2000, Aldrich and Rohde 2001, Sinclair 2006, Jenkins and Monroe 2014), and another investigates packing in conference committees (e.g. Lazarus and Monroe 2007, Vander Wielen and Smith 2011).

The origin of the modern non-voting delegates is found in the package of reforms passed by Congress in the early 1970s. Liberal members in the majority party, as well as junior representatives in both parties, supported a series of rules changes that dramatically altered how the committee system worked (Binder 1996, Schickler and Rich 1997). During the debate over the Legislative Reorganization Act of 1970, Puerto Rico's resident commissioner Jorge Cordova introduced an amendment to allow territorial delegates to serve on any standing committee. Previously, Cordova was limited to serving as an "additional members" on three committees and could not accrue seniority. He argued that the loss of three guaranteed non-voting committee seats was justified by the opportunity to be appointed, vote in, and accrue seniority in the delegates' preferred committee(s). ${ }^{7}$

The House passed the Cordova amendment by voice vote, and re-affirmed the rules changes in 1971 and 1973 to extend the same committee rights, powers, and privileges to the D.C., Guam, and U.S. Virgin Islands delegates. ${ }^{8}$ These rules changes allowed the majority party to use the territorial delegates to pack committees: there was no functional difference between House members and delegates on committees. Looking forward from 1970, majority leadership knew it could use the existing delegate and any future delegates (if they were co-partisans) to pad the party's share of seats on standing committees.

\footnotetext{
${ }^{7}$ Congressional Record, vol. 116 (09-15-1970), pp. 31848-31852

${ }^{8}$ The House elected Puerto Rico's resident commissioner to the Interior and Insular Affairs committee, and the D.C. delegate was given a designated seat on the D.C. committee. Two years later, the Guam and U.S. Virgin Islands delegates joined the Interior committee, the resident commissioner was elected to Education and Labor, and the D.C. delegate joined Banking and Currency (Holtzman 1986).
} 
Based on the literature on the partisan basis of parliamentary rights (Binder 1996) and my argument above, I first propose the following hypothesis:

H1: When the average partisanship of the delegates is closer to the majority party, members of the majority party will support proposals to expand delegate rights and members of the minority party will oppose them.

Table 1 presents a summary of the legislation to extend delegates' parliamentary rights, excluding the proposals to create new seats. The general pattern supports $\mathrm{H} 1$ : delegate rights tend to expand under Democratic majorities and do not expand under Republican majorities. As I will discuss later, Republican majorities tend to restrict the delegates' parliamentary rights relative to Democratic majorities. I provide additional evidence for minority opposition to empowering the delegates in the last section.

Table 1: Legislation to extend delegates' parliamentary rights, 1970 to 2019

\begin{tabular}{|c|c|c|c|c|}
\hline Proposed change to delegates' rights & Year & House Majority & Delegates' Party & Outcome \\
\hline Standing committee appointment $\&$ vote & 1970 & $\mathrm{D}$ & $1 \mathrm{D}$ & Passed \\
\hline Reaffirm committee vote & 1971 & $\mathrm{D}$ & $2 \mathrm{D}$ & Passed \\
\hline Committee rights to Guam \& USVI & 1973 & $\mathrm{D}$ & $4 \mathrm{D}$ & Passed \\
\hline Committee of the Whole vote & 1993 & $\mathrm{D}$ & $5 \mathrm{D}$ & Passed \\
\hline Committee of the Whole vote ${ }^{1}$ & 1998 & $\mathrm{R}$ & $5 \mathrm{D}$ & Died in Committee \\
\hline Impeachment vote for D.C. delegate & 1998 & $\mathrm{R}$ & $5 \mathrm{D}$ & Rejected by Speaker \\
\hline Discharge rights & 2004 & $\mathrm{R}$ & $4 \mathrm{D}, 1 \mathrm{R}$ & Died in Committee \\
\hline Committee of the Whole vote & 2007 & $\mathrm{D}$ & $4 \mathrm{D}, 1 \mathrm{R}$ & Passed \\
\hline Committee of the Whole vote ${ }^{2}$ & 2011 & $\mathrm{R}$ & $6 \mathrm{D}$ & Died in Committee \\
\hline Committee of the Whole vote ${ }^{2}$ & 2013 & $\mathrm{R}$ & $6 \mathrm{D}$ & Died in Committee \\
\hline Discharge rights & 2013 & $\mathrm{R}$ & $6 \mathrm{D}$ & Died in Committee \\
\hline Committee of the Whole vote ${ }^{2}$ & 2015 & $\mathrm{R}$ & $5 \mathrm{D}, 1 \mathrm{R}$ & Died in Committee \\
\hline Discharge rights & 2015 & $\mathrm{R}$ & $5 \mathrm{D}, 1 \mathrm{R}$ & Died in Committee \\
\hline Committee of the Whole vote ${ }^{2}$ & 2017 & $\mathrm{R}$ & $4 \mathrm{D}, 2 \mathrm{R}$ & Died in Committee \\
\hline Chair of Committee of the Whole & 2017 & $\mathrm{R}$ & $4 \mathrm{D}, 2 \mathrm{R}$ & Passed \\
\hline Committee of the Whole vote & 2019 & $\mathrm{D}$ & $4 \mathrm{D}, 2 \mathrm{R}$ & Passed \\
\hline
\end{tabular}

${ }^{1}$ The new Republican majority revoked CotW voting rights in $1995 .{ }^{2}$ The new Republican majority revoked CotW voting rights in 2011. 


\section{Committee packing theories}

The extant literature on committee packing focuses on the majority party's ability to pack standing and conference committees by changing their partisan composition. As regards the standing committees, various scholars point out that the majority party gives itself a higher share of committee seats than its share of seats in the House (Rohde 1991, Jenkins and Monroe 2014, Sinclair 2006, Aldrich and Rohde 2000, Aldrich and Rohde 2001). This is most obvious on the so-called power committees, such as Appropriations and Rules, that have privileged access to the floor. However, it is not limited to those committees. There is evidence that the Speaker of the House appoints loyal members of the majority party to conference committees alongside House members from the bill's jurisdictional committee (Lazarus and Monroe 2007, Vander Wielen and Smith 2011). The consequence of the so-called "Speaker's discretion" to select conference committee members is that the hand-picked majority party members can often secure policy outcomes that are more in line with the majority party's preferences.

Another strand of literature investigates the manipulation of committee size by the majority party to exert control over the policy-making process (Brady and Lee 2016). The prime example is the 1961 Rules Committee, when party leaders added enough Democrats to the committee to bypass a bipartisan coalition of conservative members that was blocking the majority's agenda with 8-8 votes (Jenkins and Monroe 2014). In the modern Congress, the property rights norm prevents the majority party leadership from removing members from a committee in order to achieve a more desirable ideological composition (Grimmer and Powell 2013). Thus, the majority leaders turn to expanding the number of seats and giving their members a super-proportion of the new seats.

To better understand the logic of packing, consider "What is the value of an additional voting member?" Under conditions where the majority leadership can introduce legislation for a vote, they would like to target bills closer to the party's ideal point. When the majority packs a committee, the intention is to use the additional member to move the median voter, in equilibrium, closer to the party's ideal point. Figure 1 illustrates this logic, where $\mathrm{L}_{1}$ is the most liberal member, $\mathrm{L}_{2}$ is the median, $L_{3}$ is the most conservative member, and $N_{1}$ and $N_{2}$ are the new members. $M_{1}$ represents 
the location of the overall median before the new member is added, and $\mathrm{M}_{2}$ shows the new median once a new (liberal) members are seated. The logic of packing applies not only to Congressional committees, but to any body of voters such as the Supreme Court (e.g. FDR's 1937 court-packing scheme) or the electorate in a campaign for office. Political parties often register new voters before an election with the hope that adding votes on the margins will push their candidate over $50 \%$.

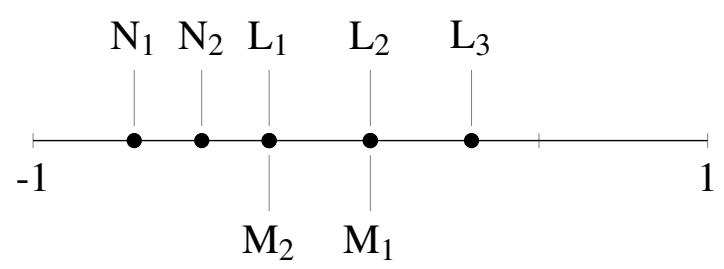

Figure 1: The logic of moving the median

In each setting, no matter the number of voters, the intention of packing is to achieve a more favorable median voter. The House majority uses several tools of procedural control and the minority party tries to respond to those tactics, such that no one form of procedural control is sufficient for majority dominance. Committee packing is one such tool, and I present evidence that the majority deploys it more extensively than the literature acknowledged.

In an era of increasing partisanship, majority parties in Congress have increasingly exploited the rules to stack the deck against the minority party. One important strand of literature suggests that the majority party can improve its control over legislative outcomes by packing the standing committees that hear and amend bills, as well as conference committees that work with the Senate to reconcile bills that have passed both houses. Previous studies on partisan control of Congress have not focused on the majority party's ability to pack a third type of committee, the Committee of the Whole (about which more later).

Based on this literature, I consider two hypotheses about the impact of adding delegates on committee size and party balance:

$\mathrm{H} 2$ : When delegates are added to a committee, the majority party will expand the size of the committee rather than replace incumbent members on the committee. 
H3: When delegates are added to committee, the majority party's share of seats on the committee will increase relative to the party's share of seats on the floor.

\section{Packing the Committee of the Whole - the Fight Over Amend-}

\section{ments}

The second way the majority party used territorial delegates to pack committees was granting them voting rights in Committee of the Whole. CotW is a procedural instrument unique to the lower chamber that allows the House leadership to move through business quickly on the floor. House leadership can move the chamber into $\mathrm{CotW}$ in order to pass procedural measures or consider amendments to bills. This section explains how the majority party faced challenges to controlling policy outcomes and sought means to exert influence over procedure to gain a marginal advantage over minority opposition.

One understudied arena in which the majority deploys committee packing is a third type of committee, Committee of the Whole. CotW is a special session of the House that allows members to consider and vote on amendments on the floor without returning legislation to the relevant standing committee. The quorum for CotW is just 100 members, rather than the 218 required to consider business on the House floor, so leaders can free up their members' time for other work. Throughout the 1980s, the majority party experienced difficulty maintaining cohesion in CotW to pass parliamentary measures and block amendments (Roberts and Smith 2003). What has gone unacknowledged by scholars, but was strongly contested at the time of the reform, is that delegates were made full members of the committee system in the early 1970s, and were eligible to vote in CotW during three sessions of Congress.

Previous scholars have not explored the use of non-voting delegates by the majority party to pack the Committee of the Whole, in part, because CotW is operationally different than standing 
committees. The majority party in Congress is not able to replace deceased or resigned minority members with majority members, nor is the Speaker given the discretion to allow or disallow certain members from participating in the committee. Furthermore, Congress cannot expand the number of Representatives for partisan advantage, and the prospects of admitting a new state are low. 9

This absence is not without reason: given that the membership of CotW is the same as the membership of the House, it is unclear that the majority party can pack CotW. Previous studies have also overlooked legislation to create seats for territorial delegates and to grant them equal rights in the committee system and Committee of the Whole. Major studies on the extent to which rules changes and parliamentary process in the House benefit majority members (Cox and McCubbins 1993, 2005; Aldrich and Rohde 2000, Binder 1996, Schickler and Rich 1997) do not include the major legislation and rules changes that empowered delegates and created new seats.

The minority party was effective at moving policy in CotW by offering amendments that drew conservative Democrats away from their party, especially after the advent of recorded votes (Smith 1989). Roberts and Smith (2003) present evidence that the parties voted differently in CotW compared to voting on the floor: Republicans voted as a united bloc on both the floor and CotW, but the Democrats experienced lower rates of party cohesion in Committee of the Whole relative to the floor. Amendments in CotW tended to focus on narrow policy issues and Republicans were effective at attracting conservative bipartisan support for ideological and symbolic votes (Roberts 2007).

Through the 1980s the majority party was looking for a way to improve party cohesion in CotW and prevent the minority party from passing amendments. The majority used restrictive rules to block the conservative coalition's amendments (Bach and Smith 1988), but Democrats still suffered defections on those CotW amendment votes that slipped through. By the early 1990s, the majority needed a new strategy to exert control on the margins where their other procedural tools had failed. They saw an opportunity in the predominantly Democratic delegates.

\footnotetext{
${ }^{9}$ The membership of the House was fixed at 435 representatives by the 1911 Apportionment Act, and has remained there since 1963 after temporary increases for Hawaii and Alaska.
} 
Here the distinctions between the House floor and Committee of the Whole are important: any procedural votes or amendments that pass in CotW can be reviewed and overturned by the House floor. Furthermore, CotW is a creation of the House rules and the voting members of the House are able to abolish CotW as if it were another standing or conference committee. Since CotW functions more like a committee than like the floor, the majority party is able to pack it using an unusual expansion strategy. At the beginning of the House session, the leadership can amend the rules to grant voting rights in CotW to the territorial delegates.

Despite the operational differences, CotW and standing committees are analytically similar when considering the value of an additional voting member. The result of packing CotW by "expansion" is similar to the effect of expanding a standing committee. If the leadership expands the committee membership by adding a greater number of majority members than minority members, then the effect of expansion is to shift the committee median toward the majority party's median (Brady and Lee 2016). Figure 2 illustrates this logic, where $\mathrm{D}_{m}$ is the median Democratic House member, $\mathrm{H}_{m}$ is the median House member (left of center), $\mathrm{R}_{m}$ is the median Republican House member. Through the late 1980s and early 1990s, the median member in CotW $\left(\mathrm{C}_{1}\right)$ was to the right of the floor median because Democrats experienced low party cohesion in the face of conservative amendments (Roberts and Smith 2003). By adding upwards of five loyal majority party members to the otherwise static membership of the House floor, the Democratic leadership could shift the committee median leftward $\left(\mathrm{C}_{2}\right)$ toward the median Democratic House member. In equilibrium, the party leadership could expect the CotW median to sit a little closer to the party's median, and on the margins, to moderate the rightward pull of the minority party's amendment strategy.

If the membership of CotW can be expanded, beyond the membership of the House of Representatives, it was advantageous for the party leadership to add additional majority members to the committee. The party leadership wanted to pack CotW with majority members, especially members who could be pressured to vote the party line, to shore up party cohesion. The addition of territorial delegates to CotW gave the majority party some space to protect their moderate mem- 


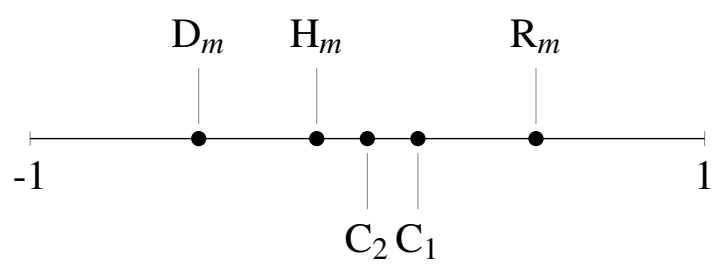

Figure 2: Moving the median in Committee of the Whole

bers in the face of the Republican amendments. Conservative Democrats were defecting from their party to support Republican-led amendments in Committee of the Whole, on roll calls and voice votes, on items on that they might not otherwise support on the floor. However, the majority party was unlikely to be able to overturn these amendments on the House floor if they were brought up for a re-vote. Based on this logic, I consider the following hypothesis about when the House majority will allow delegates to vote in Committee of the Whole:

One challenge to my theory concerns the opposition: if the conservative coalition could foresee the effect of packing CotW, why did Republicans and conservative Democrats not prevent passage of the reforms in the first place? As I show in section 4.3, the Republican Party was overwhelmingly opposed to delegate voting in CotW. Twelve Republicans, including leadership, sued in federal court to prevent the delegates from voting even after Democrats included a provision to make the delegates' votes non-pivotal. Second, the key dilemma faced by the majority party in CotW was lower cohesion on CotW votes relative to floor votes. Democrats were effective at closing ranks on floor votes, including the vote on the bundle of rules that granted voting rights to delegates. Third, even if conservative or moderate Democrats were wary of the delegates' impact on amendment votes in CotW, they likely faced competing pressure from the party to support their co-partisans and potential co-sponsors. Next, I discuss the benefits of these reforms to the majority party, its members, and the delegates themselves. 


\section{The Pay-offs of Packing}

The majority party had at least two reasons or incentives to attempt packing CotW. First, the majority party was experiencing lower rates of party cohesion in CotW relative to the House floor because Republicans were able to attract conservative Democratic votes on their amendments. The Democratic leadership sought a way to increase party cohesion by including additional loyal Democrats to CotW, and to shift the CotW median closer to the party's median (and thus the House floor).

Second, the majority party was concerned about the impact of time constraints on their ability to pass parliamentary business and put their agenda on the floor (Cox and McCubbins 2011). The majority in the late 1980s was moving into CotW more often to bypass the quorum of 218 members. The addition of up to five co-partisan delegates to CotW improved the majority party's odds of reaching the reduced quorum of 100 members and passing business at a moment's notice. The presence of co-partisan delegates in CotW would also act as insurance for majority party members who need to leave the floor to attend other business. Delegates may also "substitute" for a majority member who is unable to vote on a particular amendment, by preventing the vote margin from slipping low enough to entice moderate members to defect.

The majority party was willing to pursue the strategy to pack CotW because there were legislative, policy, and electoral payoffs for the party and individual members. The majority party in the 1980s and early 1990s moved to carry out increasing amounts of business in Committee of the Whole, such as amending bills and moving along procedural votes. Cox and McCubbins (2011) emphasize the importance of time constraints in structuring the majority party's strategies for achieving agenda control. CotW is one such device that the majority can use to advance business with a reduced quorum of 100 members, an artifact of Reed's Rules (Beth and Fauntroy 2002). CotW also allows the majority to bring up or vote down amendments to legislation on the floor while bypassing the standing committee process.

The addition of the territorial delegates to $\mathrm{CotW}$ provided insurance for the majority party when regular members needed to leave the floor and still maintain the 100 member quorum. The addition 
of five Democratic delegates would provide some cushion in the event that up to five Democrats left the floor. This would be more important when the majority members face many competing demands for their time. Of course, the minority party can use dilatory tactics such as demanding roll call votes, quorum calls, and floor re-votes on amendments passed in CotW.

Although nearly all roll call votes in Committee of the Whole counted over three or four hundred members in attendance, much of the business in CotW was done by voice vote, where attendance may have been low (near 100) ${ }^{10}$. The delegates could help the majority party meet quorum and carry out regular business or noncontroversial measures with a relative low attendance rate from their caucus; the five Democratic delegates would stand in for any five Democratic members who had competing time demands. Delegates could also serve as the chair of CotW in the 103rd, 110th, 111th, and 115th Congresses, which freed up a member of the majority party to work on other business.

There were also payoffs to the majority party and the delegates themselves from expanding voting rights in CoTW. The delegates do not otherwise possess a floor vote to "trade" with other House members, and so their vote on amendments gives them some currency with other members even when their vote isn't pivotal to the bill's outcome. The rule change also granted delegate(s) the right to preside over CotW, which increased their prestige and visibility in the process, and ingratiated them with their party's members. ${ }^{11}$ The majority party can also signal their support for the U.S. territories to their supporters, activists, and donors who may be interested in territorial policy. The payoffs can be particularly large for House members who represent districts with large populations of Americans who have a connection to the territories, such as shared ethnic or racial identity.

\footnotetext{
${ }^{10}$ Data are not available for number of members present for voice votes.

${ }^{11}$ The delegates cannot preside over the House floor, but they gained the privilege of presiding over CotW in the 103rd, 110th, and 111th Congresses. Although the Republican majority revoked the privilege in the 104th and 112th sessions, they reinstated it at the start of the 115th. The amendment was proposed by one of two Republican delegates, Amata Coleman Radewagen from American Samoa.
} 


\section{Limits to packing Committee of the Whole}

The majority party cannot run amok in the Committee of the Whole. The House rules prohibit any action in CotW from altering the proceedings of the House itself, such as changing the order of bills on the House calendar (Beth and Fauntroy 2002). Those safeguards did not assuage the minority party's fears about majority overreach.

At the start of the 103rd Congress, the Democratic leadership amended the House rules to allow the territorial delegates to vote in and preside over CotW (Rule XII), and the Republican minority responded by voting against the rules package en mass. Even after Democrats moderated their proposal by including a non-pivotal clause, the minority party was opposed: 13 members of party leadership filed a lawsuit against the delegates themselves and the Clerk of the House.

Minority leader Robert H. Michel and other Republicans argued that the expansion of delegates' rights in Committee of the Whole was unconstitutional, in part, because it granted legislative power to members that did not represent states. The plaintiffs also noted that the rule change halved the majority party's seat losses in the previous year's election. The Democratic defendants argued that the House rules grant the majority the power to amend the committee system, and that CotW was more akin to a standing committee than the House floor (Palmer 2006, Beth and Fauntroy 2002). Almost any action taken in CotW, including amendments passed with the support of the territorial delegates, could be reconsidered on the House floor if 25 members rose with such a demand.

To preempt Republican opposition to the rule change, the Democratic majority also amended Rule XXIII to stipulate that the delegates could not be decisive or pivotal in any vote in Committee of the Whole. In the event that the delegates votes were decisive in the passage or failure of an amendment, the House would reconsider the amendment on the House floor and the delegates would be stripped of their vote. Despite the saving clause, House Republicans proceeded with a lawsuit against the Clerk of the House, suggesting that the minority party thought the addition of delegates to CotW would hurt its ability to impact policy.

The controversy surrounding delegate voting in Committee of the Whole centered on the ex- 
tent to which delegates were exercising legislative power. Federal courts found that CotW is a creation of House rules and decisions made there are reversible by the House itself. Only four votes were automatically taken because of this rule in the six years that delegates possessed the right to vote in CotW. Judges on the U.S. District Court of D.C. and U.S. Court of Appeals for the D.C. Circuit upheld the rules changes and suggested that the pivotality rule made the delegates' votes "meaningless". 12

One criticism of delegate voting from a minority party leader, Rep. Gerald Solomon, is suggestive of why the minority party opposed delegate voting and is consistent with my theory. Solomon argued that delegates could exercise negative agenda control despite the 'savings clause' that stipulated their votes cannot be pivotal. Under the 1993 rules, amendments that passed or failed with a vote margin within the pivotal window (how ever many delegates had voted on that particular measure, up to 5) would be automatically subject to re-vote, and any 25 members could force any amendment passed in CotW to be reconsidered on the floor. Members of the House could not, however, force a re-vote on an amendment that failed in CotW by a vote margin outside the pivotal window. Thus, it was possible for territorial delegates to pad a vote margin just outside the pivotal window, making a vote look closer than it was and making it harder to negotiate with the truly pivotal members. In this case, the minority party would not retain the ability to force a floor vote to consider, and Solomon suggested this dynamic was at play in a vote on the Selective Service System in 1993 (CQ Almanac 1993).

The CotW packing strategy was inherently limited. Any 25 members (except delegates themselves) can demand a floor vote for any amendment that passes the CotW, whether or not the delegates are pivotal, a strategy that Republicans employed in the 103rd Congress to delay proceedings and strip the delegates of their votes (the vast majority of the re-votes did not change the outcome). The delegates could propose amendments, just as they could propose legislation, but still lacked discharge rights in CotW. Nevertheless, the extent to which the parties were willing to fight over (and litigate) the delegates' rights suggests that they thought these reforms were meaningful and

\footnotetext{
${ }^{12}$ Michel v. Anderson, 817 F. Supp. 147-148 (District of D.C. 1993); Michel v. Anderson, 14 F.3d 623 (D.C. Circuit 1994).
} 
had the potential to shift policy on the margins.

\section{Data and Results}

This paper uses a combination of tests to provide evidence that the majority used delegates to pack standing committees and Committee of the Whole. Following the literature, I consider the impact of adding delegates on standing committee sizes and the extent to which the majority party is over-represented. I show that the addition of delegates resulted in larger committees in nearly $2 / 3$ of cases and greater Democratic representation in $3 / 5$ of cases. To test claims about packing in CotW, I collect a novel dataset of delegates' votes and present the first ideal point estimates for those members based on roll-call data. I show that the addition of delegates in 1993 moved the CotW median nearly $2 \%$ closer to the majority party. The paper concludes with evidence that the minority party, and some conservative Democrats, mounted opposition to these reforms.

Table 2 presents the party composition of the delegate seats over that time period.

Table 2: Party Composition of Territorial Delegates, 1970-2018

\begin{tabular}{|c|c|c|c|c|}
\hline Territory (1st term) & Perc. Democrats & Democrats & Republicans & Independents \\
\hline Puerto Rico (1901) & $88 \%$ & 21 & 3 & 0 \\
\hline District of Columbia (1971) & $100 \%$ & 24 & 0 & 0 \\
\hline U.S. Virgin Islands (1973) & $91 \%$ & 21 & 1 & 1 \\
\hline Guam (1973) & $83 \%$ & 19 & 4 & 0 \\
\hline American Samoa (1980) & $89 \%$ & 17 & 2 & 0 \\
\hline Northern Mariana Islands (2008) ${ }^{1}$ & $100 \%$ & 2 & 0 & 3 \\
\hline
\end{tabular}

${ }^{1}$ Northern Mariana Islands delegate Gregorio K.C. Sablan was elected as an Independent in 2008, 2014, and 2016, and as a Democrat in 2010 and 2012. He caucuses with the Democratic Party in the House. As of autumn 2019, one proposal for a new seat is pending before Congress: a representative for the Cherokee Nation authorized by the Treay of New Echota (1835).

\section{Evidence in Standing committees}

The main tool that the majority party can deploy to exert its influence over a standing committee is to increase the size of the committee by adding more seats (Brady and Lee 2016). The most famous example of this expansion strategy was the Rules Committee in 1961, when two Democrats and 
one Republican were added to break the hold of conservative Democrats who blocked policy on tie votes. The property rights norm protects the current committee members from being removed from their seats, but the majority can bypass the norm and shift the median voter toward the party's ideal position by expanding the number of seats (Brady and Lee 2016). Committee sizes were changing through the 1970 s and 1980 s and it is at least plausible that the majority party used the expansion strategy during this period to pack committees with delegates.

In order to test this claim, I examine how committee size and the rate of Democratic overrepresentation changed when a new delegate was appointed to a particular committee. ${ }^{13}$ I identify all the new appointments of a delegate representing territory $\mathrm{j}$ to a committee $\mathrm{k}$ at time $\mathrm{t}>1970$, totalling 22 appointments between the 93rd and 103rd Congresses. For each new appointment, I calculate the change in committee size over time, $\Delta \mathrm{N}_{k t}=\mathrm{N}_{k t}-\mathrm{N}_{k, t-1}$, where $\mathrm{N}_{k t}$ is the number of seats on committee $\mathrm{k}$ at time $\mathrm{t}$. Thus $\Delta \mathrm{N}_{k t}$ is positive if the committee grew in size when the new delegate was appointed, 0 when the committee did not change in size, and negative if the committee was reduced in size. Table 3 presents the results of this test of the committee size hypothesis, $\mathrm{H} 2$ . Nearly two thirds $(64 \%)$ of new delegate appointments were associated with an increase in the number of committee seats, while a quarter (27\%) of appointments were associated with smaller committee sizes.

Table 3: The effect of delegate appointments on committee size, 93rd-103rd Congresses

\begin{tabular}{|l|c|}
\hline Number of delegate appointments such that $\Delta N_{k t}>0$ & $14(64 \%)$ \\
\hline Number of delegate appointments such that $\Delta N_{k t}=0$ & $2(9 \%)$ \\
\hline Number of delegate appointments such that $\Delta N_{k t}<0$ & $6(27 \%)$ \\
\hline Total number of new delegate appointments & 22 \\
\hline
\end{tabular}

Next, I calculate changes in the rate of majority party representation on committees that receive a new delegate to test the over-representation hypothesis, H3. Committees are considered "packed" when there is a higher proportion of majority party members, in this case Democrats, than their party's share of floor seats. For each new appointment, I calculate $\Delta \mathrm{OVER}_{k t}=\mathrm{OVER}_{k t}$

\footnotetext{
${ }^{13}$ Data on committee membership from Nelson and Stewart \& Woon (both accessed 12/2017)
} 
- OVER $_{k, t-1}$, where OVER $_{k t}$ is the over-representation of Democrats on committee $\mathrm{k}$ at time $\mathrm{t}$. Thus, OVER $k t$ is positive if the Democrats became more over-represented when a new delegate was appointed, 0 if there was no change, and negative if Democrats became less over-represented. Table 4 presents a summary of the results. Nearly three fifths of new delegate appointments (59\%) were associated with an increase in the share of committee seats held by Democrats relative to their share of seats on the floor. Nine appointments $(41 \%)$ were associated with a decline in Democratic over-representation, although in each case the party continued to be over-represented relative to the floor. On average, the presence of a territorial delegate on a committee was associated with Democrats being 2 percentage points more over-represented (see table 6 in the appendix, model 4).

Table 4: Delegate committee appointments and Democratic over-representation, 93rd-103rd Congresses

\begin{tabular}{|l|c|}
\hline Number of delegate appointments such that $\triangle O V E R_{k t}>0$ & $13(59 \%)$ \\
\hline Number of delegate appointments such that $\triangle O V E R_{k t}=0$ & 0 \\
\hline Number of delegate appointments such that $\triangle O V E R_{k t}<0$ & $9(41 \%)$ \\
\hline Total number of new delegate appointments & 22 \\
\hline
\end{tabular}

\section{Evidence in Committee of the Whole}

The first step to testing the plausibility of the majority party packing CotW is to empirically estimate the ideal point of the median voter in CotW based on the roll call vote record. Previous studies of roll call voting in Committee of the Whole tend to drop the delegates form the data even in those Congresses where they possessed voting rights (e.g. Roberts and Smith 2003). If the delegates are not included in the nearly 1,200 roll call votes taken in CotW, then the ideal point estimates for House members in CotW during the 103rd, 110th, and 111th Congresses are likely biased. Although the absence of five members out of 440 total House members, in just three sessions, is unlikely to have an impact on any major findings in the literature on Congress, the exact size and direction of the bias have not been estimated and futures studies of roll call voting in 
Table 5: Moving the median with delegates in Committee of the Whole

\begin{tabular}{|c|c|c|c|c|c|}
\hline Congress & $\begin{array}{c}\text { Dem. Delegates } \\
\text { left of median }\end{array}$ & $\begin{array}{c}\text { Dem. Delegates } \\
\text { right of median }\end{array}$ & $\begin{array}{c}\text { Movement } \\
\text { of median }\end{array}$ & $\begin{array}{c}\text { Avg Member } \\
\text { Attendance }\end{array}$ & $\begin{array}{c}\text { Delegate } \\
\text { Attendance }\end{array}$ \\
\hline 103rd & 4 & 1 & -0.018 & $96.1 \%$ & $84.2 \%$ \\
\hline 110th & 2 & 2 & -0.001 & $96.5 \%$ & $77.0 \%$ \\
\hline 111th & 0 & 6 & +0.009 & $96.7 \%$ & $82.0 \%$ \\
\hline
\end{tabular}

Congress could benefit from the insights gained from finding out.

To estimate the effect of packing on the CotW median ideal point, I use 1,173 roll call votes in three Congresses to estimate each members' ideal point with the emIRT package in R (Imai, Lo, and Olmsted 2016).House roll call data were taken from VoteView and I collected the delegates' CotW votes from Congress.gov. First, I calculate the median member in CotW, as well as the median House Democrat and House Republican based on the roll call votes excluding the delegates. Next, I add the delegates' votes on roll call items in CotW and re-estimate each members' ideal points and the medians.

Table 5 presents estimated ideal points from a binary item response model (IRT) using yes and no votes coded 1 and -1 , respectively. The estimates for House member ideal points are then scaled between -1 and 1 . The results are consistent with our expectations: the CotW median is closer to the median Democrat in the House compared to the CotW median as calculated without the delegates. In the 103rd Congress, the average ideal point estimate for the delegates was -0.24 , just to the right of the median Democrat (-0.28) and to the left of the median House member (-0.04). The addition of the delegates shifts the CotW to the left by 0.02 , equivalent to approximately $2.4 \%$ of the distance between the median Democrat and Republican (0.84). ${ }^{14}$ Returning to the analogy of a tightly-contested campaign (Section 2.2), it is worth considering whether a political party would think it is worthwhile to pursue a strategy that moves the vote margin by $2.4 \%$ on average. Committee packing with delegates is no panacea, but the effect on the margins makes it worthwhile in the modern era of increasing partisan warfare.

Previous studies show that the CotW median tended to be more conservative than the floor

\footnotetext{
${ }^{14}$ This result may be attenuated by the inclusion of all roll call votes from CotW, including uncontroversial amendments that passed with large bipartisan majorities.
} 
median, but we do not need to display the floor median here to test the claim about committee packing. The key assertion in this section is that the majority party sought to shift the CotW median toward the majority party median (i.e. to the left). That claim is borne out by the evidence. The finding that the CotW median was to the right of the floor median leading up to 1993, as shown by Roberts and Smith (2003), further supports the claim that Democrats had an incentive to pursue this strategy. The majority might have pursued the expansion strategy even if the CotW and floor medians were the same: Democrats had lost nine seats in the 1992 elections and were facing a rightward shift in the floor median in 1993 relative to 1992 . The addition of five Democratic delegates halved those losses and moderated the rightward shift of the CotW median no matter where the floor median lay.

In later years, the addition of delegates to CotW had a negligible effect on the CotW median, which was further to the left in 2007-2011 than 1993-1995 (see Table 7 in the appendix). The average attendance rate for delegates was lower in the later Congresses, and the delegates with the highest ideal point estimates (i.e. less liberal) tended to miss the most votes. ${ }^{15}$ More research is needed to determine if the majority party relied less on delegates in CotW over time as polarization increased and party cohesion rose.

\section{Evidence of Minority Party Opposition}

To provide an additional test of the claim that the majority party used delegates to pack standing committees and CotW, it is worthwhile to discuss the extent and form of the minority party's opposition to these reforms. If the majority party did pursue a packing strategy, we would expect to observe the other party taking steps to mitigate the impact of delegates after party control of the House changes. This response is most obvious in the case of Committee of the Whole: Republicans changed the House rules to remove delegates from CotW after gaining majority status in 1995 and

${ }^{15}$ Among the Democratic delegates in the 110th-111th Congresses, the American Samoa and Guam delegates were the least liberal and missed the most votes. It is worth noting that the delegates from these territories must travel farther from their district to Capitol Hill than any other member: between 7,000 and 8,000 miles. 
2011. It is not clear why such reversals were worthwhile if the delegates' presence in CotW was meaningless or symbolic. In the case of standing committees, the Republicans did not need to take extra measures to mitigate the impact of added delegates. The majority party exercises discretion over the ratio of its own members to members of the minority party on each committee, and given that most delegates were Democrats, their impact on committee medians will be mitigated when they are in the minority.

There is evidence that Republicans and many conservative Democrats were opposed to the creation of new delegate seats in the 1970s, although the measures did pass comfortably. Figure 3 shows the party breakdown on the vote to create the D.C. delegate, and figure 4 presents the same for the vote to create delegates for Guam and the U.S. Virgin Islands (note: Aye votes are represented by empty dots, Nay votes by solid dots). The two votes were not particularly close but the partisan breakdown of the opposition is consistent with the theory presented in this paper. Although most Democrats and Republicans supported creating a delegate for D.C. (314-68), many of the most extreme members of the two parties were opposed. Southern Democrats, in particular, joined many Republicans on the right to vote against the new seat. This pattern of opposition was more pronounced in the vote two years later to create the Guam and USVI delegates (251123). Several liberal Republicans joined others in their party, along with many conservative and moderate Democrats, to oppose these two seats.

One possible explanation for Republican opposition to the reforms that empowered delegates may be that the party and its members oppose the existence of the institution and do not support granting parliamentary rights to delegates out of principle. This explanation is not supported by the historical record: Republicans sponsored legislation to create delegate seats for other territories and were generally supportive of the institution. In 1977, for example, six conservatives led by Senator Jesse Helms (R-NC) sponsored a bill to create a new delegate for Americans living in the Panama Canal Zone. The bill never received a vote, however, since the Senate and President Carter were concurrently debating the return of the Canal Zone to the Panamanian government. Republicans were also instrumental in the movement for a delegate for the Northern Mariana 


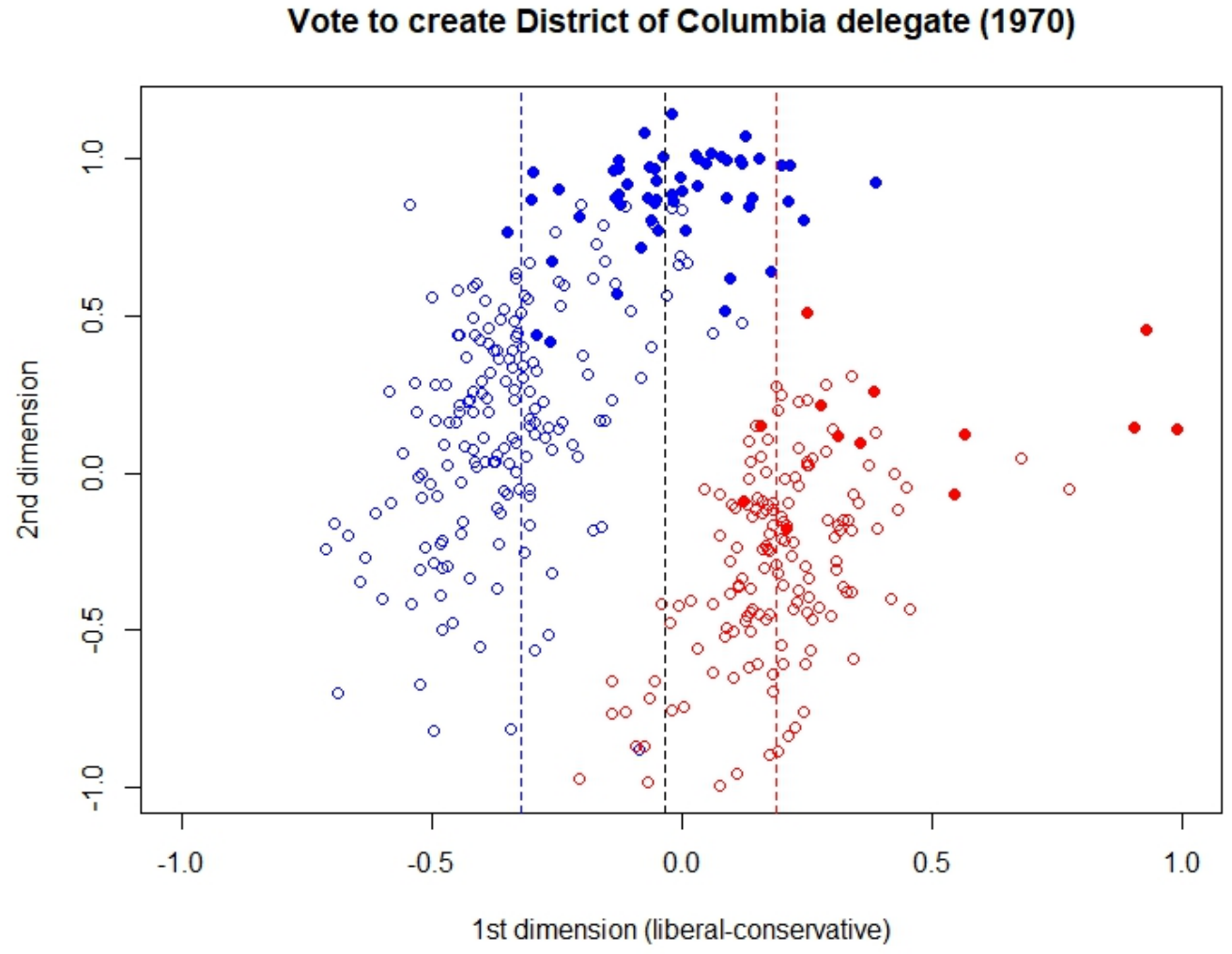

Figure 3: Aye votes are empty dots, Nay votes are solid dots. Democrats are blue, Republicans are red.

Islands, introducing early legislation for that purpose in 1996 and 2005. Although these bills were unsuccessful at the time, they suggest that the Republican Party is not opposed to the existence of the delegates as an institution, but rather that they make a calculated choice to oppose delegate voting when it would disadvantage the GOP in the policy process.

The Republican Party was also vehemently opposed to the addition of delegates to Committee of the Whole. In addition to bloc voting against the enacting legislation and litigating the issue in federal court for over a year, Republicans also changed their behavior in CotW after delegates started voting. Republicans argued that the majority party overstepped its bounds to gain an advantage in policy-making, but despite minority party fear about the majority abusing the delegates to pass "close" votes, the delegates were only decisive on four votes in CotW across three Congresses, and only one automatic re-vote led to the outcome being reversed. ${ }^{16}$

\footnotetext{
${ }^{16}$ The delegates cast decisive votes on three amendments in the 103rd Congress: roll call \#63
} 


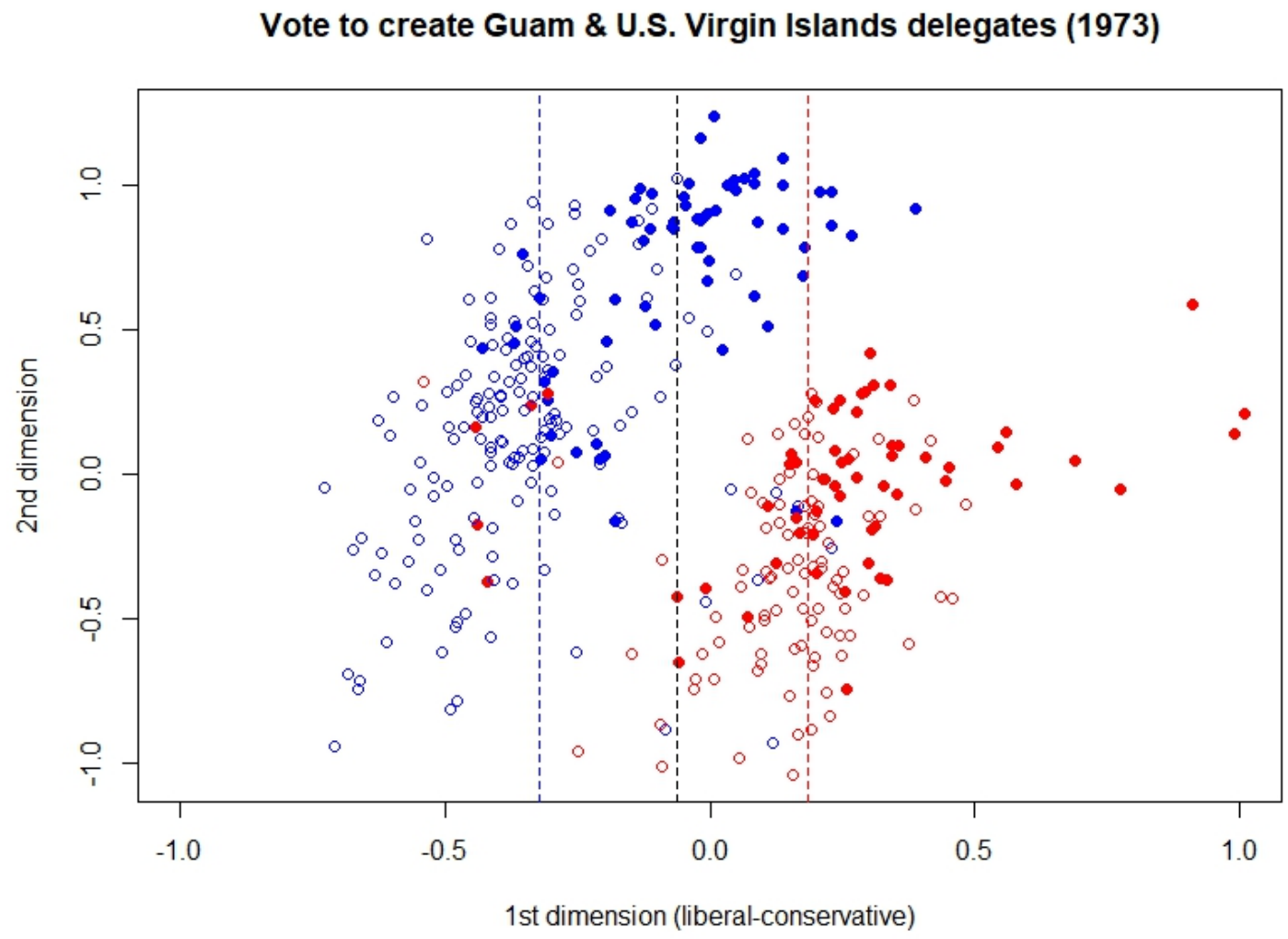

Figure 4: Aye votes are empty dots, Nay votes are solid dots. Democrats are blue, Republicans are red.)

The claim that the territorial delegates exercised out-sized legislative power in CotW by masking the vote margin between regular members is dubious: House members know that the delegates' votes cannot be pivotal and should thus be aware of the 'true' vote margin during negotiations. Even if Rep. Solomon's assessment is accurate (sec. 4.3), it is hard to identify other cases where this might have happened. Only 28 of 1,158 votes (2.4\%) were within single digit margin, including the four votes that were automatically retaken (only one of which changed outcome) and the Selective Service case. Just two amendments were failed and then automatically re-voted on due to the 'savings clause'. Eighteen other amendments (1.6\%) failed by single digit margins but could not be reconsidered on the floor because the delegates' votes were not pivotal.

Even if the delegates could not be pivotal, the minority party acted as though their votes mat(03/17/1994), roll call \#267 (06/23/1994), and roll call \#277 (06/24/1994). The delegates were decisive once in the 111th Congress: roll call \#360 (06/18/2009). 
tered by demanding significantly more re-votes on amendments passed in CotW than in previous Congresses. Nearly 10 percent of amendments passed in CotW were brought up for a re-vote on the floor. Figure 5 shows the precipitous rise in re-votes that House members, mostly Republicans, demanded in the 103rd Congress. The pattern is consistent with the idea that the minority party was responding to the majority party's packing strategy and the use of CotW to pass legislative business under a more favorable set of rules.

\section{Re-votes on amendments from Committee of the Whole}

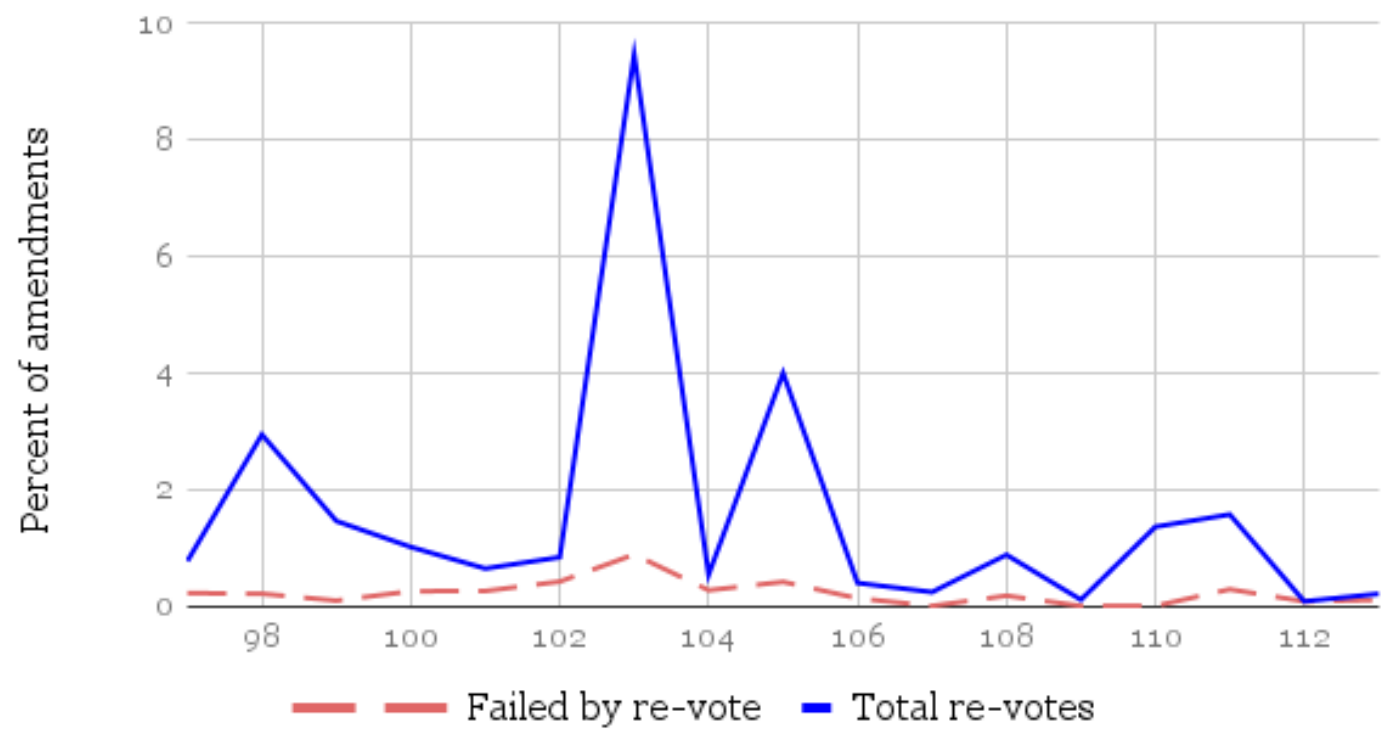

Figure 5

\section{Conclusion}

Partisan conflict over the territorial delegates' voting rights has become a regular feature of modern American politics. This paper makes multiple contributions to the literature on partisanship in Congress. First, I show that the majority party possesses two previously unknown tools to gain advantage in the legislative process: adding new delegates to pack standing committees and granting delegates voting rights in order to pack the Committee of the Whole. These strategies are absent from the literature on partisan theories of Congress, despite the the near-continuous fighting be- 
tween the two parties over the delegates' rights whenever majority control of the House changes hands.

Second, I show that the majority party had the right incentives to deploy these strategies in the latter quarter of the 20th century, as the conservative coalition was obstructing their agenda in standing committees and CotW. The majority passed legislation and rules changes to create new delegates and expand their committee rights in the 1970s with overwhelming support from liberals and sizable opposition from Republicans and conservative Democrats, suggesting the two factions were at odds over the impact of such reforms. This paper presents the first statistical evidence that these changes in the House rules allowed the majority party to increase its representation on standing committees, as well as CotW.

Previous studies that present ideal points based on roll call votes exclude the delegates, resulting in bias for the three sessions in which delegates could vote in CotW: 103rd, 110th, and 111th. I remedy that issue by contributing the first ideal point estimates for the delegates based on newlycollected vote data. My results show that the CotW median was closer to the majority party median when we include the delegates' votes than when the delegates are excluded, at least in the 103rd Congress. In the 110th and 111th Congresses, the delegates were not systematically closer to the majority party median than the CotW median, and thus did not apply the same leftward pressure that delegate appear to have applied in the 103rd Congress. These results suggest that although the addition of delegates to committees can occur during periods of high polarization, the addition of delegates does not itself contribute to party polarization.

Finally, a key insight from this research is that the tools in the majority party's toolkit are not all equal in effect size. The extant literature points to high-impact strategies that allow the party leadership to maximize their control over the policy-making process, but there are those tools like committee packing that can be deployed on the margins. Taken together, the theory and empirical results in this paper show us that majority leadership is willing to consider any strategy to give their party an advantage, no matter how peripheral the tactic or nominal the impact. Substantively, these results contribute to our knowledge of an understudied institution that represents over 5 million 
Americans. 


\section{References}

Aldrich, John H., and David W. Rohde. (2000). The consequences of party organization in the House: The role of the majority and minority parties in conditional party government. Polarized politics: Congress and the President in a partisan era.

Aldrich, John, and David W. Rohde. (2001). The logic of conditional party government: Revisiting the electoral connection. Congress Reconsidered, ed. Dodd, Lawrence and Bruce Oppenheimer, 7th edition. Washington, DC: Congressional Quarterly Press.

Bach, Stanley J., and Steven S. Smith. (1988). Managing uncertainty in the House of Representatives: adaption and innovation in special rules. Brookings Institution Press, 1988.

Beth, Richard S., and Michael K. Fauntroy. (2002). Is the Committee of the Whole the House? Implications of Michel v. Anderson for District of Columbia Representation. Paper delivered at annual meeting of American Political Science Association.

Binder, Sarah A. (1996). The partisan basis of procedural choice: Allocating parliamentary rights in the House, 1789-1990. American Political Science Review 90.1: 8-20.

Bonica, Adam. (2016). Database on Ideology, Money in Politics, and Elections: Public version 2.0 [Computer file]. Stanford, CA: Stanford University Libraries. https://data.stanford.edu/dime

Brady, Michael C., and Daniel Lee. (2016). Another tool in the party toolbox? Tracing the strategic expansion of committee size in the US House, 1947-2010. Party Politics 22.6: 784-796.

Davis, Christopher M. (2017). Parliamentary rights of the delegates and the resident commissioner from Puerto Rico. Congressional Research Service.

Delegates got 'symbolic' floor vote. (1994). CQ Almanac 1993, 49th ed., 75-76. Washington, DC: Congressional Quarterly. 
Fowler, James H. (2006a). Connecting the Congress: A study of cosponsorship networks. Political Analysis 14.4: 456-487.

Fowler, James H. (2006b). Legislative cosponsorship networks in the US House and Senate. Social Networks 28.4: 454-465.

Holtzman, Abraham. (1986). Empire and representation: The U.S. Congress. Legislative Studies Quarterly vol. 11, no. 2: 249-273.

Imai, Kosuke, James Lo, and Jonathan Olmsted. (2016). Fast estimation of ideal points with massive data. American Political Science Review 110.4: 631-656.

Jenkins, Jeffery A., and Nathan W. Monroe. (2014). Negative agenda control and the conservative coalition in the US House. The Journal of Politics 76.4: 1116-1127.

Lazarus, Jeffrey, and Nathan W. Monroe. (2007). The Speaker's discretion: Conference committee appointments in the 97th through 106th Congresses. Political Research Quarterly 60.4: 593-606.

Lewallen, Jonathan. (2017). From rules to representation: Teaching about the territories and their delegates in the US Congress.” PS: Political Science \& Politics vol. 50, no. 2: 497-500.

Lewallen, Jonathan, and Bartholomew H. Sparrow. "Nothing on the Floor: Congress, the Territorial Delegates, and Political Representation.” Political Science Quarterly 133.4 (2018): 729-752.

Lewis, Jeffrey B., Keith Poole, Howard Rosenthal, Adam Boche, Aaron Rudkin, and Luke Sonnet. (2017). Voteview: Congressional Roll-Call Votes Database.

Mamet, Elliot (2018). Representation on the Periphery: Non-Voting Members of Congress and Imaginative Representation. Working paper. 12 November. 
McCarty, Nolan, Keith Poole and Howard Rosenthal. (2000). Congress and the territorial expansion of the United States. New directions in studying the history of the U.S. Congress, David Brady and Mathew McCubbins (eds). Stanford: Stanford University Press.

Nelson, Garrison. (n.d.) Committees in the U.S. Congress, 1947-1992, [House/87th-102rd], [Accessed: 12/01/2017].

Palmer, Betsy. (2006). Territorial delegates to US Congress: Current issues and historical background. Congressional Research Service.

Roberts, Jason M., and Steven S. Smith. (2003). Procedural contexts, party strategy, and conditional party voting in the US House of Representatives, 1971-2000. American Journal of Political Science 47.2: 305-317.

Roberts, Jason M. (2007). The statistical analysis Of roll-call data: A cautionary tale. Legislative Studies Quarterly 32.3: 341-360.

Rohde, David W. (1991). Parties and leaders in the postreform House. University of Chicago Press.

Schickler, Eric, and Andrew Rich. (1997). Controlling the floor: Parties as procedural coalitions in the House. American Journal of Political Science: 1340-1375.

Sinclair, Barbara. (2006). Party Wars: Polarization and the politics of national policy making. Norman: University of Oklahoma Press.

Smith, Steven S. (1989). Call to order: Floor politics in the House and Senate. Brookings Inst Press.

Stewart, Charles, and Barry R. Weingast. (1992). Stacking the Senate, changing the nation: Republican rotten boroughs, statehood Politics, and American political development. Studies in American Political Development 6.02: 223-271. 
Stewart, Charles and Jonathan Woon. (2017). Congressional committee assignments, 103rd to 114th Congresses, 1993-2017: [House], [Accessed: 12/01/2017].

Vander Wielen, Ryan J., and Steven S. Smith. (2011). Majority party bias in US congressional conference committees. Congress \& the Presidency. Vol. 38, No. 3. Taylor \& Francis Group. 


\section{Appendix}

\section{Non-voting members in other legislatures}

The U.S. Congress is unique among legislatures for featuring non-voting members. The closest approximation of the non-voting delegates in the U.S. House of Representatives can be found in the Maine state legislature. Maine's House of Representatives features three non-voting member seats that represent three Native American tribes residing in the state. ${ }^{17}$ These members are given limited privileges to sponsor legislation on tribal policy and cosponsor other bills, but they may not vote on the House floor. Similar to the U.S. House delegates, however, the tribal members may be appointed to standing committees, where they may debate and cast votes on bills and amendments.

Congress is also unique among national legislatures for providing nonvoting seats to citizens not living in states, provinces, or the equivalent. Both the National Assembly and Senate of France, for example, allow French citizens living in overseas territories to elect members with full voting rights from the "Overseas constituency". ${ }^{18}$ Twenty-one Senators and twenty-seven deputies participate fully in French Parliament alongside the members representing mainland France. One reason for the difference in territorial representation may be that French overseas citizens comprise a larger share of their country's population than citizens living in U.S. territories: $4 \%$ of French citizens compared to $1.5 \%$ of Americans. The other advanced democracies with a history of colonialism do not provide any representation in Parliament for overseas citizens, including Great Britain, Germany, and the Netherlands (Holtzman 1986).

\footnotetext{
${ }^{17}$ Maine's nonvoting delegates represent the Penobscot Nation, the Passamaquoddy Tribe, and the Maliseet Tribe.

${ }^{18}$ The French overseas constituency is comprised of thirteen areas: five regions (Guadeloupe, French Guiana, Martinique, Réunion, Mayotte) and eight territories (French Polynesia, Saint Pierre and Miquelon, Wallis and Futuna, Saint Martin, Saint Barthélemy, French Southern and Antarctic Lands, New Caledonia, and Clipperton Island). The European Parliament also recognizes the Overseas constituency, even those outside of Europe, and allows French citizens living there to elect members with full voting rights.
} 


\section{Challenges to Measuring Delegate Activity}

\section{Testing Theories of Packing: The Challenges of Measuring Delegate Activity}

There are challenges to testing partisan theories of Congress when the nonvoting delegates are involved, namely their absence from the datasets commonly used by political scientists. For example, one consequence of the delegates lacking a floor vote is that they are absent from major datasets on ideology in Congress. Ideal point estimates based on roll call voting, such as DWNominate, do not include the delegates because they do not cast votes on floor items. Similarly, interest groups that score members based on votes, such as the Americans for Democratic Action and the American Conservative Union, do not release delegate scores.

Furthermore, the delegates' votes are not included on those votes where they were allowed to participate, such as CotW amendments in 1993-1995 and 2007-2011. Even when scholars have separated the roll call votes to re-estimate ideal points for the House floor and CotW, the five or six delegates are not accounted for in the periods when they possessed voting rights (Roberts and Smith 2003, Roberts 2007).

GovTrack rates members on ideology and leadership based on patterns of sponsorship and cosponsorship, which the delegates are allowed to do in the House. Political science datasets on co-sponsorship, however, systematically drop the delegates (Fowler 2006a, 2006b). The delegates may be excluded from some studies, in part, because they are not assigned ICPSR member codes and cannot be easily matched to other Congressional datasets. ${ }^{19}$

Given these limitations in the data, it is difficult or impossible to perform the conventional tests of committee packing. For example, we cannot observe the change in standing committee medians in the 1970 s after the majority party added delegates because there are no conventional measurements of ideology, based on roll-calls or otherwise, for the delegates in that period. Previous estimates of committee medians that use measures of ideology based on floor roll-call votes do

\footnotetext{
${ }^{19}$ A notable exception is the Dataset on Ideology, Money in Politics, and Elections (Bonica 2016), which estimates ideal points for political candidates, including the delegates, based on campaign contributions.
} 
not account for this missing data problem, although this may be solved by estimating committeespecific ideal points for all members (including the delegates) with committee roll-calls. Another test of committee packing might consider whether the addition of delegates resulted in the majority party winning more votes in the packed committee. If the majority party was experiencing opposition in the committees in the form of close votes, then we might expect to observe fewer close votes after the delegate(s) are added. This approach is not an effective test of packing because it does not account for the movement of policy in accord with the committee median (which is unobservable). The committee chairmen only allow votes on those bills that can pass the committee with $50 \%$ support, i.e. those that are acceptable to the median member. Since the objective of packing is to shift the median toward the party's median, not necessarily to overwhelm the other party on every vote, it is plausible that we could continue observe close votes in committee when bills are moving closer to the party's preference.

\section{Democratic over-representation and delegate appointment}

Table 6 presents the results of four regression tests for the relationship between the presence of a delegate on a committee and the degree to which the majority party is over-represented relative to their share of House seats. The dependent variable is the difference between the percent of Democrats on committee $\mathrm{k}$ and the percent of floor seats held by Democrats at time $\mathrm{t}$ (i.e. in a given Congress). The results of models 1 and 2 show that the committees that received delegates between 1961 and 1994 did not, on average, have a greater share of Democrats than other committees. Not all committees are valued equally, and the null results could be due to differences in the partisan makeup of certain committees prior to addition of territorial delegates. High-value committees such as Rules, Ways and Means, and Armed Services, for example, may have already been "packed" and, thus, the majority party did not need to add more members in the form of delegates. To account for this possibility, model 3 includes committee fixed effects and shows that Democrats were over-represented on committees that received delegates by $2.8 \%$ on average. After accounting for changes over time, the results show that the majority enjoyed a $2 \%$ advantage 
on the committees featuring territorial delegates (model 4).

Table 6: Delegates on Committees and Democratic Over-Representation

\begin{tabular}{lcccc}
\hline \hline & \multicolumn{5}{c}{ Dependent variable: } \\
\cline { 2 - 5 } & \multicolumn{4}{c}{ Over-representation (percent) } \\
& $(1)$ & $(2)$ & $(3)$ & $(4)$ \\
\hline Delegate & 0.65 & 0.09 & $2.84^{* * *}$ & $1.80^{* *}$ \\
& $(0.74)$ & $(0.74)$ & $(0.82)$ & $(0.85)$ \\
& & & & \\
Constant & $3.00^{* * *}$ & 0.80 & -0.02 & -1.68 \\
& $(0.39)$ & $(1.48)$ & $(1.15)$ & $(1.56)$ \\
Congress Fixed Effects & & & & \\
Committee Fixed Effects & No & Yes & No & Yes \\
\hline Observations & 336 & 336 & 336 & 336 \\
$\mathrm{R}^{2}$ & 0.00 & 0.12 & 0.38 & 0.48 \\
Adjusted $\mathrm{R}^{2}$ & 0.00 & 0.06 & 0.34 & 0.42 \\
\hline \hline
\end{tabular}

Note: ${ }^{*} \mathrm{p}<0.1 ;{ }^{* *} \mathrm{p}<0.05 ;{ }^{* * *} \mathrm{p}<0.01$ 
Table 7: Ideal Point Estimates from Committee of the Whole

\begin{tabular}{|l|c|c|c|c|}
\hline \multicolumn{1}{|c|}{ Congress } & $\begin{array}{c}\text { CotW } \\
\text { median }\end{array}$ & $\begin{array}{c}\text { Democrat } \\
\text { median }\end{array}$ & $\begin{array}{c}\text { GOP } \\
\text { median }\end{array}$ & $\begin{array}{c}\text { Delegate } \\
\text { average }\end{array}$ \\
\hline 103rd (without delegates) & -0.02 & -0.26 & 0.55 & - \\
\hline 103rd (with delegates: 5/5 Democrats) & -0.04 & -0.28 & 0.56 & -0.23 \\
\hline 110th (without delegates) & -0.27 & -0.64 & 0.37 & - \\
\hline 110th (with delegates: 4/5 Democrats) & -0.27 & -0.64 & 0.36 & -0.16 \\
\hline 111th (without delegates) & -0.43 & -0.68 & 0.37 & - \\
\hline 111th (with delegates: 6/6 Democrats) & -0.42 & -0.68 & 0.33 & -0.29 \\
\hline
\end{tabular}

Table 8: New delegate appointments to standing committees, 93rd to 103rd Congress

\begin{tabular}{|c|l|c|c|}
\hline Congress & Committee & Committee Size & Dem. Over-representation \\
\hline 93rd & Education and Labor & Decrease & Decrease \\
93rd & Banking and Currency & Increase & Decrease \\
93rd & District of Columbia & Increase & Decrease \\
93rd & Interior \& Insular Affairs & Increase & Decrease \\
94th & Banking, Currency, Housing & Decrease & Increase \\
94th & Interior \& Insular Affairs & Increase & Increase \\
94th & Merchant Marine \& Fisheries & Increase & Increase \\
95th & Education and Labor & Decrease & Increase \\
95th & Interior \& Insular Affairs & Increase & Increase \\
97th & Merchant Marine \& Fisheries & Decrease & Decrease \\
97th & Public Works \& Transportation & No effect & Decrease \\
97th & Veterans' Affairs & No effect & Decrease \\
97th & Post Office \& Civil Service & Increase & Increase \\
99th & Interior \& Insular Affairs & Decrease & Decrease \\
99th & Banking, Finance, Urban Affairs & Increase & Decrease \\
100th & Foreign Affairs & Increase & Increase \\
101st & Education and Labor & Increase & Increase \\
102nd & Foreign Affairs & Decrease & Increase \\
102nd & Education and Labor & Increase & Increase \\
102nd & Merchant Marine \& Fisheries & Increase & Increase \\
102nd & Public Works \& Transportation & Increase & Increase \\
103rd & Education and Labor & Increase & Increase \\
\hline
\end{tabular}

